\title{
Evaluation of the memory CD4+ and CD8+ $T$ cells homeostasis during chronic venous disease of lower limbs
}

\author{
Dominika Ojdana ${ }^{1}$, Kamil Safiejko ${ }^{2}$, Robert Milewski ${ }^{3}$, Paweł Sacha ${ }^{1}$, \\ Piotr Wieczorek $^{1}$, Alina Lipska ${ }^{4}$, Piotr Radziwon ${ }^{4}$, Jacek Dadan ${ }^{2}$ \\ and Elżbieta Tryniszewska ${ }^{1}$
}

\author{
${ }^{1}$ Department of Microbiological Diagnostics, Medical University of Bialystok, Poland \\ ${ }^{2}$ Ist Department of General and Endocrinological Surgery, Medical University of Bialystok, Poland \\ ${ }^{3}$ Department of Statistics and Medical Informatics, Medical University of Bialystok, Poland \\ ${ }^{4}$ Regional Centre for Transfusion Medicine in Bialystok, Poland
}

\begin{abstract}
More and more is known about the role of venous wall abnormalities and valvular incompetence in the development of chronic venous disorders (CVD). Unfortunately detailed mechanisms of CVD pathophysiology are not well understood. Recent studies focus on involvement of the inflammatory process in the structural remodeling of venous valvues and venous wall. The aim of this study is to investigate and to document the memory $T$ cells homeostasis in CVD patients. In this study we present lymphocytic changes in blood from varicose veins in terms of total CD4+ and CD8+ T cells and their particular subsets of memory $\mathrm{T}$ cells: $\mathrm{T}_{\mathrm{N}}, \mathrm{T}_{\mathrm{CM}}$ and $\mathrm{T}_{\mathrm{EM}}$. Results suggest that immunological memory may be involved in the CVD development.
\end{abstract}

Key words: memory $\mathrm{T}$ cells, chronic venous disease, inflammatory process

\section{Introduction}

All cells if the immune system arise from multipotent stem cells which undergo differentiation, maturation and migration from primary lymphoid organs into secondary lymphoid organs [1,2].

$\mathrm{CD} 4+$ and $\mathrm{CD} 8+\mathrm{T}$ cells subpopulations play important biological functions [3]. CD4+ cells are called helper $\mathrm{T}$ cells [4]. They generate or stimulate production of specific cytokines, and then they influence on inflammatory process $[5,6]$. CD $8+\mathrm{T}$ cells are called cytotoxic $\mathrm{T}$ cells [7]. They have the ability for activation, suppression and cytotoxicity [8]. Heterogenous population of these cells is studied to characterize CD4+ memory T cells and CD8+ memory T cells with their subsets: central memory cells, effector memory cells and naive memory cells [9].

Memory $\mathrm{T}$ cells population have ability to survive in host after the completion of the immune response and they provide long-term protection against reinfec-

Correspondence: E. Tryniszewska, Dept. of Microbiological Diagnostics, Medical University of Bialystok, J. Waszyngtona Str. 15A, 15-269 Bialystok, Poland; tel./fax: (+4885) 7468571, e-mail: zdmik@umwb.edu.pl tion [10]. Speed and effectiveness of the secondary response upon reinfection depends on qualitative and quantitative differences of memory $\mathrm{T}$ cells in comparison with naive cells $[11,12]$. Precise mechanisms of memory $\mathrm{T}$ cells development steal are not well understood $[13,14]$. There are four potential mechanisms which may lead to the generation of memory cells [15]. The first model establishes the presence of separate naive precursors of effectors and memory $\mathrm{T}$ cells, in contrast to the second model which establishes that $\mathrm{T}$ cells constitute uniform population of precursors [16]. According to the third one, memory cells are derived directly from effector cells [17]. The influence of a level and time of stimulus duration for the generation of memory $\mathrm{T}$ cells considered in the fourth model of memory T cells formation [18].

Memory $\mathrm{T}$ cells are heterogenous in terms of their phenotype, anatomical distribution and functional properties [19]. The difference in occurrence of the CC chemokine receptor 7 (CCR7) and L-selectin (CD62$\mathrm{L})$ on the memory $\mathrm{T}$ cells surface is characteristic feature of these cells used to subdivide them into two functionally distinct $\mathrm{T}$ cells subsets $[20,21]$. Memory $\mathrm{T}$ cells may be defined as central memory $\mathrm{T}$ cells $(\mathrm{CM})$ 
and effector memory T cells (EM). CM cells exhibits presence of the CCR7 and high expression of CD62L [22]. However on the EM cells lack is CCR7 and the expression level of CD62L is low [23]. Besides, identification of the memory $\mathrm{T}$ cells based on the expression of CD45RA on their surfaces, allows to differentiation of TEMRA among CD8+ T cells [24]. Other memory $\mathrm{T}$ cells subsets do not exhibit CD45RA expression on their surface. In the line with distinct expression of markers on memory $\mathrm{T}$ cells surface, they exhibit different localization [25]. CM cells mainly are present in secondary lymphoid organs and EM T cells in peripheral nonlymphoid tissues [26]. Differences in the phenotype of memory CD4+ and CD8+ T cells influence on different functions which these cells play in immune response. EM T cells provide a first line of defense against antigen. These cells are able to extravasate into peripheral tissues and they have a high potential of immediate effector functions. CM T cells are responsible for maintaining long-term protection upon reinfection. They have a high proliferative capacity and little potential of immediate cytotoxic function $[27,28]$.

The pathophysiology of chronic venous disease (CVD) is not well understood, but it is known that always inflammatory changes are present. Moreover, the inflammatory process is investigated as the major cause of CVD [29].

Chronic venous disease (CVD) is a very common disease, which is significant social, medical and economic problem. The reason of the majority of CVD symptoms, (teleangiectases, varicose veins, edema, trophic changes, chronic leg ulceration), is prolonged venous hypertension caused by venous wall abnormalities and venous valves incompetence [30]. Recent advantages in understanding of CVD are focused on role of the leukocytes in the CVD pathogenesis [31]. In CVD patients, intense infiltration of leukocytes mostly lymphocytes and neutrophiles, was observed. Lymphocytic changes may suggest implication of immunological memory in the CVD pathogenesis. Chronic elevation of the venous pressure may cause leukocytes and endothelial cells activation [32]. The extravasation process of leukocytes is divided into rolling, activation, adhesion and transendothelial migration [33]. The extravation process of leukocytes is complicated and involves interactions between endothelial cells and leukocytes. During rolling leukocytes attach loosely to endothelial cells by L-selectin and E-selectin [34]. Leukocytes during the rolling process may meet various chemoattractants, (interleukin 8 (IL-8), complement split products, macrophage inflammatory protein (MP-1 $\beta$ ) and Nformyl peptides), which biding with leukocytes surface receptors cause their activation [35]. The shedding of adhesion molecules from leukocytes surface occur as the result of the activating signal. Level of soluble L-selectin was higher in CVD patients [36]. The activating signal induces also a conformational changes in the integrin molecules which results in increment of their affinity for Ig-superfamily adhesion molecules. The interaction of integrins and Ig-superfamily adhesion molecules causes firm adhesion of leukocytes to the endothelial cells and their migration through the endothelium [37]. Activated leukocytes migrate into venous wall and venous valve [38]. Leukocytes during the inflammatory process generate numerous substances (e.g.: proteolytic enzymes, free radicals and cytokines), which are responsible for the changes of the venous wall and venous valve, which lead to venous wall destruction and valvular incompetence [39].

The aim of the study was to investigate and to document the memory $\mathrm{T}$ cells homeostasis (central, effector and naive memory T cells) in CVD patients versus hospitalized abdominal hernia patients. We also evaluated their correlations.

\section{Materials and methods}

Patient samples. Group A: 9 patients, 7 women and 2 men aged $32-65$, were included in the study. All patients were hospitalized for surgical removal, by crio-stripping, of varicose veins of the lower extremities due to chronic venous disorder (CVD). CVD severity was evaluated using the CEAP (clinical, etiologic, anatomic, pathophysiologic) classification. Two 10-ml EDTA blood samples were obtained from all patients prior to the surgery.

The first blood sample was obtained from a superficial forearm vein unaffected by CVD. The second blood sample was taken from a superficial lower limb vessel affected by CVD. Prior to obtaining blood from a lower limb venous vessel, each patient remained in an upright position for 20 minutes to provoke a venous stasis in the pathological superficial venous vessels.

Group B. 4 patients, 2 women and 2 men aged 19-35, hospitalized due to abdominal-wall hernia and scheduled for celotomy, were qualified for the study. None of the control group members displayed CVD signs. Blood samples were obtained from a superficial forearm vein unaffected by CVD directly before surgery.

Isolation of lymphocytes. Mononuclear cells were isolated from peripheral blood (PBMC). They were isolated by mechanical Ficoll gradient centrifugation.

Flow cytometry analysis. Fresh mononuclear cells were directly stained with anti-human CD4 APC Ab (APC labeled, clone Mouse $\mathrm{IgG}_{1} \kappa, \mathrm{BD}$ Pharmingen), anti-human CD $8 \beta$ PE Ab (PE labeled, clone 2ST8.5H7, Beckman), anti-human CD28 FITC Ab (FITC labeled, clone CD28.2, BD Pharmingen), anti-human CD95 Ab ( PE-Cy5 labeled, clone DX2, BD Pharmingen).

Briefly, $1 \times 10^{6}$ lymphocytes isolated by Ficoll were incubated with previously described Abs for 30 minutes at room temperature. After washing the cells twice in Dulbecco's phosphate buffered saline supplemented with $2 \%$ FCS and fixation in $1 \%$ paraformaldehyde, samples were analyzed by flow cytometry using The BD FACSCalibur ${ }^{\mathrm{TM}}$ system.

For the analysis the memory $\mathrm{T}$ cell population was identified on forward and side scatter for the lymphocyte population and on CD4 and CD8 expression. $\mathrm{T}_{\mathrm{CM}}$ were identified as $\mathrm{CD} 28+/ \mathrm{CD} 95+$, 
$\mathrm{T}_{\mathrm{EM}}$ as $\mathrm{CD} 28-/ \mathrm{CD} 95+$ and $\mathrm{T}_{\mathrm{N}}$ as CD28+/CD95-. The date are presented as percentages of total CD4 and CD8 or as percentages of $\mathrm{T}_{\mathrm{N}}, \mathrm{T}_{\mathrm{CM}}$ and $\mathrm{T}_{\mathrm{EM}}$ memory cells.

Statistical analysis. The normality of data was evaluated by the Kolgomorow-Smirnow test and non-normal distribution was observed in analyzed groups. Statistical analysis was performed using of the nonparametric U-Mann-Whitney test. Correlations were assessed using the Spearman correlation method. Values of $\mathrm{p}<0.05$ were considered as statistically significant. In calculations Statistica 8.0 software was used.

\section{Results}

After gating on lymphocyte region lymphocytes were identified as CD4+ T cells and CD8+ T cells and measured. In the next step $\mathrm{T}_{\mathrm{N}}, \mathrm{T}_{\mathrm{CM}}$ and $\mathrm{T}_{\mathrm{EM}}$ were characterized by the expression of CD28 and CD95 and were measured.

The quantitative evaluation of total $\mathrm{CD} 4+$ and $\mathrm{CD} 8+\mathrm{T}$ cells and their particular subsets of memory $\mathrm{T}$ cells: $\mathrm{T}_{\mathrm{N}}, \mathrm{T}_{\mathrm{CM}}$ and $\mathrm{T}_{\mathrm{EM}}$ in peripheral blood in group $\mathrm{A}$ shows that the level of total CD4+ was higher than total CD8+ in peripheral blood. Among memory T cells subsets, the level of $\mathrm{T}_{\mathrm{CM}}$ was the highest and the level of $\mathrm{T}_{\mathrm{EM}}$ was the lowest (Fig. 1a). The level of total CD4+ and CD8+ $\mathrm{T}$ cells and their particular subsets of memory $T$ cells: $T_{N}, T_{E M}$ and $T_{C M}$ was also measured in blood from varicose veins in group A. The level of total CD4+ was higher than total CD8+. High levels of $\mathrm{T}_{\mathrm{CM}}$ were observed. The level of $\mathrm{T}_{\mathrm{N}} \mathrm{CD} 8+$ was higher than $\mathrm{T}_{\mathrm{EM}} \mathrm{CD} 8+$, whereas the level of $\mathrm{T}_{\mathrm{N}} \mathrm{CD} 4+$ was lower than $\mathrm{T}_{\mathrm{EM}} \mathrm{CD} 4+$ (Fig. 1b). Measurements of total CD4+ and CD8+ $\mathrm{T}$ cells and their particular subsets of memory $\mathrm{T}$ cells: $\mathrm{T}_{\mathrm{N}}, \mathrm{T}_{\mathrm{CM}}$ and $\mathrm{T}_{\mathrm{EM}}$ in peripheral blood in group $\mathrm{B}$ also show the higher level of total CD4+ than total $\mathrm{CD} 8+$ and that among memory $\mathrm{T}$ cells subsets the level of $\mathrm{T}_{\mathrm{CM}}$ was the highest and of $\mathrm{T}_{\mathrm{EM}}$ was the lowest (Fig. 1c).

In this study we also show the comparison between of total CD4+ and CD8+ and particular subsets of memory $T$ cells: $T_{N}, T_{C M}$ and $T_{E M}$ in peripheral blood, among group $\mathrm{A}$ and group $\mathrm{B}$. No statistically significant differences were found between group $\mathrm{A}$ and group B in terms of total CD4+ and CD8 $+\mathrm{T}$ cells and particular subsets of memory $\mathrm{T}$ cells: $\mathrm{T}_{\mathrm{N}}, \mathrm{T}_{\mathrm{CM}}$ and $\mathrm{T}_{\mathrm{EM}}$ (Fig. 2).

Moreover, we demonstrate correlations in group A between peripheral blood and blood from varicose veins in terms of total CD4+ and CD8+ $\mathrm{T}$ cells and particular subsets of memory $\mathrm{T}$ cells: $\mathrm{T}_{\mathrm{N}}, \mathrm{T}_{\mathrm{CM}}$ and $\mathrm{T}_{\mathrm{EM}}$ (Fig. 3). There were almost full correlations of total CD4 $+\mathrm{T}$ cells $(\mathrm{r}=0.91 ; \mathrm{p}<0.05)$, total CD8 $+\mathrm{T}$ cells $(\mathrm{r}=0.96 ; \mathrm{p}<0.05)$ and $\mathrm{T}_{\mathrm{CM}} \mathrm{CD} 8+$ cells $(\mathrm{r}=0.95$; $\mathrm{p}<0.05$ ). Furthermore, there were very high correlations of $\mathrm{T}_{\mathrm{CM}} \mathrm{CD} 4+$ cells $(\mathrm{r}=0.76 ; \mathrm{p}<0.05), \mathrm{T}_{\mathrm{EM}} \mathrm{CD} 4+$ cells $(\mathrm{r}=0.83 ; \mathrm{p}<0.05)$ and $\mathrm{T}_{\mathrm{EM}} \mathrm{CD} 8+$ cells $(\mathrm{r}=0.71$; $\mathrm{p}<0.05)$. Whereas in $\mathrm{T}_{\mathrm{N}} \mathrm{CD} 4+$ cells $(\mathrm{r}=0.68 ; \mathrm{p}<0.05)$
Group A - peripheral blood

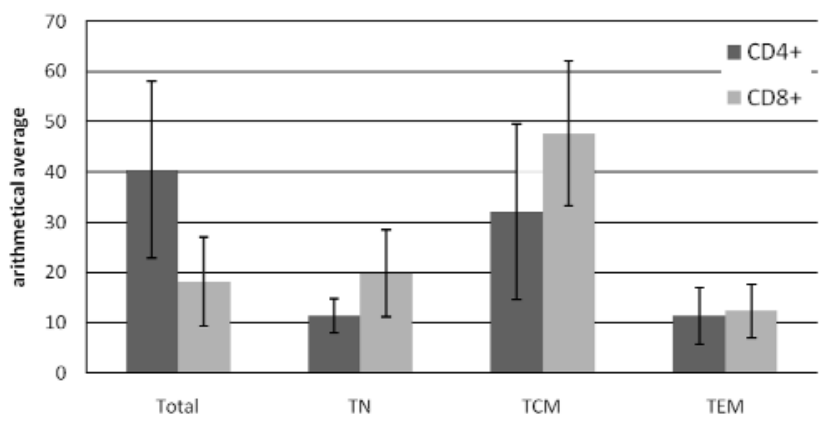

Group A - blood from varicose veins

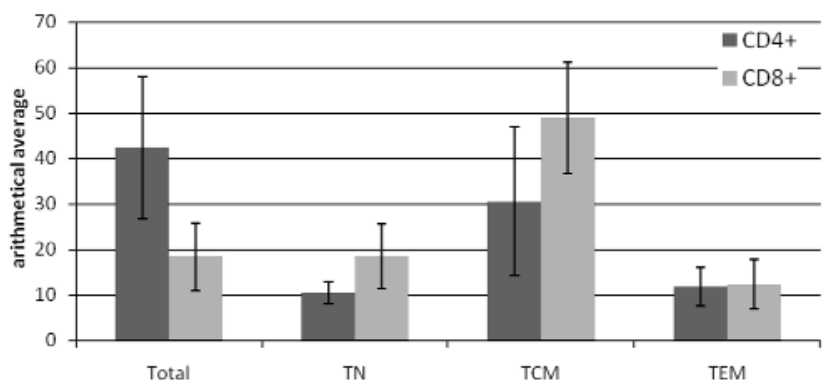

Group B - peripheral blood

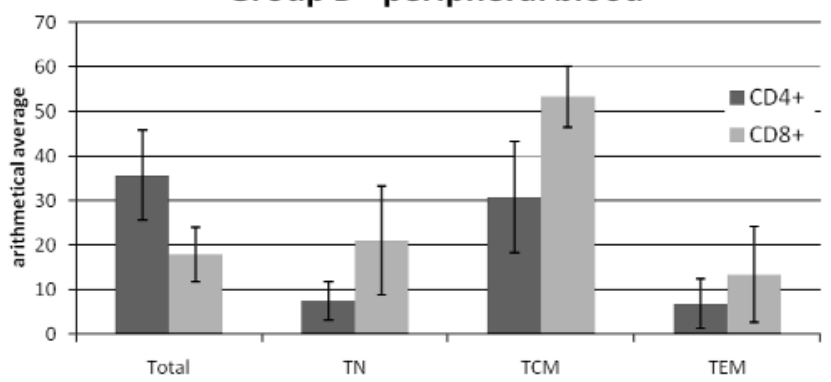

Fig. 1. The quantitative evaluation of total $\mathrm{CD} 4+$ and $\mathrm{CD} 8+$ and particular subsets of memory $\mathrm{T}$ cells: $\mathrm{T}_{\mathrm{N}}, \mathrm{T}_{\mathrm{CM}}$ and $\mathrm{T}_{\mathrm{EM}}$ in group $\mathrm{A}$ and group B.

and $\mathrm{T}_{\mathrm{N}} \mathrm{CD} 8+$ cells $(\mathrm{r}=0.63 ; \mathrm{p}<0.05)$ were high correlations. All correlations were statistically significant besides correlation of $\mathrm{T}_{\mathrm{N}} \mathrm{CD} 8+$ cells.

\section{Discussion}

Chronic venous disease is very significant problem among Western population $[40,41]$. Chronic venous disease is one of the most common disease, but precise mechanisms of its pathophysiology remains not well known [42]. The role of the valvular incompetence and venous wall abnormalities in the pathophysiology is well understood. Less is known about the reasons which lead to the development of these changes [43].

Recent studies indicate that always there is present an inflammatory process during the development of CVD [44]. In this study using identification of total CD4+ and CD8+ and particular subsets of memory $\mathrm{T}$ 

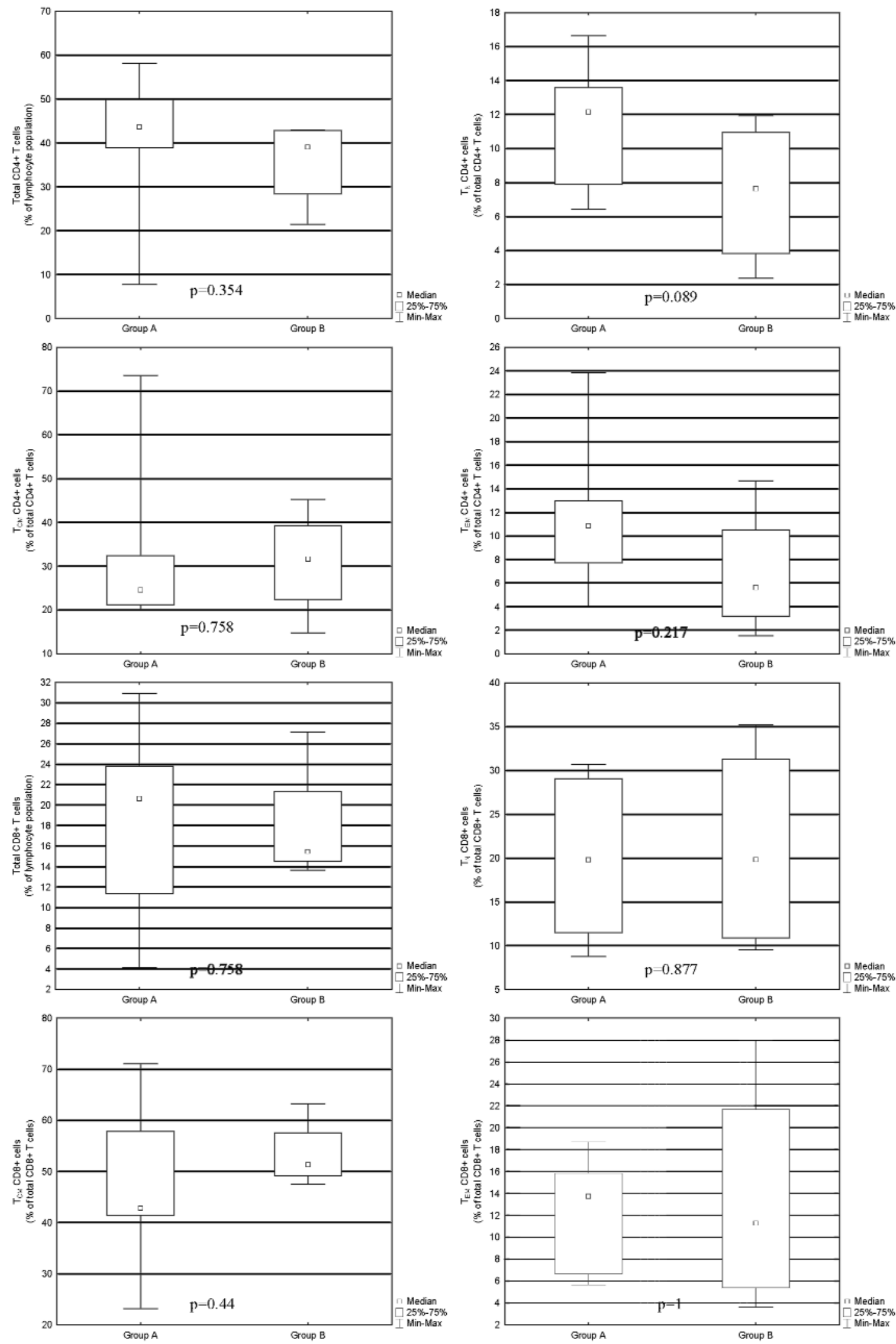

Fig. 2. The comparison between total $\mathrm{CD} 4+$ and $\mathrm{CD} 8+$ and particular subsets of memory $\mathrm{T}$ cells: $\mathrm{T}_{\mathrm{N}}, \mathrm{T}_{\mathrm{CM}}$ and $\mathrm{T}_{\mathrm{EM}}$ in peripheral blood, among group A and group B. 

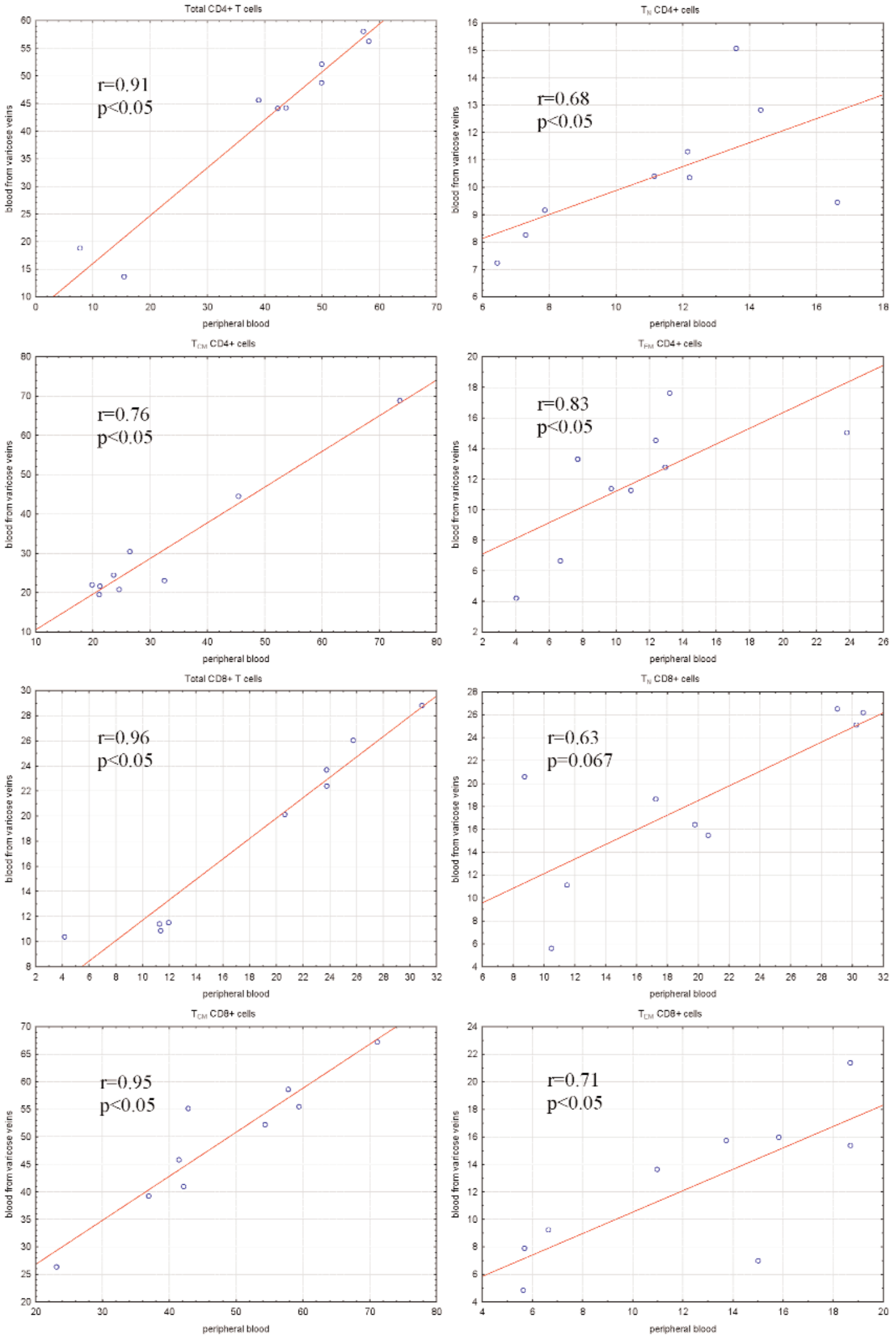

Fig. 3. Correlations in group A between peripheral blood and blood from varicose veins in terms of total CD4+ and CD $8+$ and particular subsets of memory $\mathrm{T}$ cells: $\mathrm{T}_{\mathrm{N}}, \mathrm{T}_{\mathrm{EM}}$ and $\mathrm{T}_{\mathrm{CM}}$. 
cells: $\mathrm{T}_{\mathrm{N}}, \mathrm{T}_{\mathrm{CM}}$ and $\mathrm{T}_{\mathrm{EM}}$, based on the expression of CD4, CD8, CD28 and CD95, we show the memory T cells homeostasis in CVD patients versus hospitalized abdominal hernia patients.

We have demonstrate that no statistically significant differences were between group A and group B in terms of total CD4+ and CD8+ $\mathrm{T}$ cells and particular subsets of memory $\mathrm{T}$ cells: $\mathrm{T}_{\mathrm{N}}, \mathrm{T}_{\mathrm{CM}}$ and $\mathrm{T}_{\mathrm{EM}}$ in peripheral blood. While, there were statistically significant difference between peripheral blood and blood obtained from varicose veins in terms of previously described $\mathrm{T}$ cells subsets. These results are important implication about the presence of local inflammatory conditions.

Results presented in this study show enhanced values of $\mathrm{T}$ cells subpopulations in blood from varicose veins which can be regarded as lymphocytic changes. Measurements of particular subsets of memory T cells: $\mathrm{T}_{\mathrm{N}}, \mathrm{T}_{\mathrm{CM}}$ and $\mathrm{T}_{\mathrm{EM}}$ in blood from varicose veins show that the level of $\mathrm{T}_{\mathrm{CM}}$ the highest and the level of $\mathrm{T}_{\mathrm{EM}}$ was the lowest. These findings lead us to speculate that immunological memory T cells may be involved in the CVD pathogenesis.

Moreover, the result of the increased level of lymphocytes in blood obtained from varicose veins is related to studies focused on intense inflammatory cells infiltration (mainly lymphocytes) in the venous valves and venous wall [45]. Leukocytes undergo activation during chronic elevation of the blood pressure in veins [46]. Activated cells migrate into valvular and venous wall and may be responsible for the changes of the venous wall and venous valve. Several studies show enhanced infiltration of lymphocytes, monocytes, macrophages and neutrophils into venous wall [32]. Inflammatory cells may release proteolityc enzymes, free radicals and cytokines responsible for the destruction of tissue $[47,48]$.

Particular understanding of the inflammatory process in the development of chronic venous disease may be significant for treatment of that disease or even for its prevention.

\section{References}

[ 1] Ceredig R, Rolink AG, Brown G. Models of haematopoiesis: seeing the wood for the trees. Nat Rev Immunol. 2009;9:293300.

[ 2] Cyster JG. Chemokines and cell migration in secondary lymphoid organs. Science.1999; 286:2098-2102.

[ 3] Lanzavecchia A, Sallusto F. Dynamics of T lymphocyte responses: intermediates, effectors, and memory cells. Science. 2000;290:92-97.

[ 4] Zhu J, Paul WE. CD4 T cells: fates, functions, and faults. Blood. 2008;1:1557-1569.

[ 5] Romagnani S. T-cell subsets (Th1 versus Th2). Ann Allergy Asthma Immunol. 2000;85:9-18.

[ 6] Romagnani S. Regulation of the T cell response. Clin Exp Allergy. 2006;36:1357-1366.
[ 7] Harty JT, Tvinnereim AR, White DW. CD8(+) T cell effector mechanisms in resistance to infection. Annu Rev Immunol. 2000;18:275-308.

[ 8] Harty JT, Badovinac VP. Influence of effector molecules on the $\mathrm{CD} 8(+) \mathrm{T}$ cell response to infection. Curr Opin Immunol. 2002;14:360-365.

[ 9] Kalia V, Sarkar S, Gourley TS, Rouse BT, Ahmed R. Differentiation of memory B and T cells. Curr Opin Immunol. 2006; 18:255-264

[10] Wherry EJ, Ahmed R. Memory CD8 T-Cell differentiation during viral infection. J Virol. 2004;78:5535-5545.

[11] Ahmed R, Gray D. Immunological memory and protective immunity: understanding their relation. Science. 1996;272: 54-59.

[12] Ahmadzadeh M, Hussain SF, Farber DL. Heterogeneity of the memory CD4+ cell response: persisting effectors and resting memory T cells. J Immunol. 2001;166:926-935.

[13] Lanzavecchia A, Sallusto F. Understanding the generation and function of memory T cell subsets. Curr Opin Immunol. 2005; 17:326-332.

[14] Sprent J, Surh CD. Generation and maintenance of memory T cells. Curr Opin Immunol. 2001;13:248-254.

[15] Ojdana D, Safiejko K, Lipska A, Radziwon P, Dadan J, Tryniszewska E. Effector and memory CD4+ and CD8+ T cells in the chronic infection process. Folia Histochem Cytobiol. 2008;46:413-417.

[16] Stemberer C, Neuenhahn M, Buchholz VR, Busch DH. Origin of CD8+ effector and memory cell subsets. Cell Mol Immunol. 2007;4:399-405.

[17] Seder RA, Ahmed R. Similarities and differences in CD4+ and CD8+ effector and memory cells generation. Nat Immunol. 2003;4:835-842.

[18] Lanzavecchia A, Sallusto F. Dynamics of T lymphocyte responses: intermediates, effectors, and memory cells. Science. 2000;290:92-97.

[19] Cush SS, Anderson KM, Ravneberg DH, Weslow-Schmidt JL, Flano E. Memory generation and maintenance of CD8+ T cell function during viral persistence. J Immunol. 2007;179:141153.

[20] Hikono H, Kohlmeier JE, Takamura S, Wittmer ST, Roberts $\mathrm{AD}$, Woodland DL. Activation phenotype, rather than centralof effector- memory phenotype, predicts the recall efficacy of memory CD8+ T cells. J Exp Med. 2007;204;1625-1636.

[21] Willinger T, Freeman T, Hasegawa H, McMichael AJ, Callan MFC. Molecular signatures distinguish human central memory from effector memory CD8 T cell subsets. J Immunol. 2005; $175: 5895-5903$

[22] Sallusto F, Geginat J, Lanzavecchia A. Central memory and effector memory $\mathrm{T}$ cell subsets: function, generation, and maintenance. Annu Rev of Immunol. 2004;22:745-763.

[23] Lefrancois L, Masopust D. T cell immunity in lymphoid and non-lymphoid tissues. Curr Opin Immunol. 2002;14:503-508.

[24] Beverley PC. Primer: making sense of T-cell memory. Nat Clin Pract Rheumatol. 2008;4:43-49.

[25] Willinger T, Freeman T, Hasegawa H, McMichael AJ, Callan MFC. Molecular signatures distinguish human central memory from effector memory CD8 T cell subsets. J Immunol. 2005;175:5895-5903.

[26] Campbell DJ, Debes GF, Johnston B, Wilson E, Butcher EC. Targeting $\mathrm{T}$ cell responses by selective chemokine receptor expression. Semin Immunol. 2003;15:277-286.

[27] Sallusto F, Lenig D, Forster R, Lipp M, Lanzavecchia A. Two subsets of memory $\mathrm{T}$ lymphocytes with distinct homing potentials and effector functions. Nature. 1999;401:708-712.

[28] Weninger W, Crowley MA, Manjunath N, von Andrian UH. Migratory properties of naive, effector, and memory CD8 cells. J Exp Med. 2001;194:953-966. 
[29] Weninger W, Manjunath N, von Adrian UH. Migration and differentiation of CD8 T cells. Immunol Rev. 2002;186:221233.

[30] Ojdana D, Safiejko K, Lipska A et al. The inflammatory reaction during chronic venous disease of lower limbs. Folia Histochem Cytobiol. 2009;47:1-5.

[31] Tran NT, Meissner MH. The epidemiology, pathophysiology, and natural history of chronic venous disease. Seminars in Vascular Surgery. 2002;15:5-12.

[32] Bergan J. Molecular Mechanisms in Chronic Venous Insufficiency. Ann Vasc Surg. 2007;21:260-266

[33] Sayer GL, Smith PD. Immunocytochemical characterisation of the inflammatory cell infiltrate of varicose veins. Eur $J$ Vasc Endovasc Surg. 2004 Nov;28(5):479-83.

[34] Gohel MS, Windhaber RAJ, Tarlton JFT, Whyman MR, Poskitt KR. The relationship between cytokine concentrations and wound healing in chronic venous ulceration. J Vasc Surg. 2008;48:1272-1277.

[35] Barreiro O, Sanchez-Madrid F. Molecular basis of leukocyteendothelium interactions during the inflammatory response. Rev Esp Cardiol. 2009 May;62(5):552-62.

[36] Ley K. Integration of inflammatory signals by rolling neutrophils. Immunological Reviews. 2002;186:8-18, 2002.

[37] Penberthy TW, Jiang Y, Graves DT. Leukocyte adhesion molecules. Crit Rev Oral Biol Med. 1997;8:380-388.

[38] Saharay M, Shields DA, Porter JB, Scurr JH, Coleridge Smith PD. Leukocyte activity in the microcirculation of the leg in patients with chronic venous disease. J Vasc Surg. 1997;26: 265-273.

[39] Langer HF, Chavakis T. Leukocyte-Endothelial Interactions in Inflammation. J Cell Mol Med. 200916.
[40] Boisseau MR. Leukocyte involvement in the signs and symptoms of chronic venous disease. Perspectives for therapy. Clin Hemorheol Microcirc. 2007;37:277-290.

[41] Rusinowicz T, Wardyn KA. Patient with chronic venous insufficiency in genaral practitioner's practice. Family Medicine \& Care Review. 2006;8:1092-1097.

[42] Bergan J, Molecular Mechanisms in Chronic Venous Insufficiency. Ann Vasc Surg. 2007;21:260-266.

[43] Noszczyk W. Chronic venous insufficiency. Terapia. 2005; 12:11-16.

[44] Nicolaides AN. Chronic Venous Disease and the leukocyteendothelium interaction:from symptoms to ulceration. Angiology. 2005;56:S11-S19.

[45] Schmid-Schonbein GW, Takase S, Bergan JJ. New advances in the understanding of the pathophysiology of chronic venous insufficiency. Angiology. 2001;52:S27-S34.

[46] Bergan JJ, Schmid-Schonbein G, Colleridge-Smith P, Nicolaides A, Boisseau M, Eklof B. Chronic venous disease. $N$ Engl J Med. 2006;355:488-498.

[47] Takase S, Delano FA, Lenrod L, Bergan JJ, Schmid-Schonbein GW. Inflammation in chronic venous insufficiency: is the problem insurmountable? J Vasc Res. 1999;36:3-10.

[48] Saharay M, Shields DA, Porter JB, Scurr JH, Coleridge Smith PD. Leukocyte activity in the microcirculation of the leg in patients with chronic venous disease. J Vasc Surg. 1997;25: 265-273.

Submitted: 10 August, 2009 Accepted after reviews: 19 October, 2009 